\title{
Recognition and Protection Customary Law Community in Indragiri Hulu Regency of Riau Province
}

\author{
Auradian Marta ${ }^{1}$ \\ \{auradian_unri@yahoo.com ${ }^{1}$ \} \\ Universitas Riau, Indonesia $^{1}$
}

\begin{abstract}
This study is based on the absence of policies established by the Regional Government to recognize and protect the existence of indigenous and tribal peoples in Indragiri Hulu Regency. This study seeks to discuss why local governments in the current democratic era have not been able to make policies on the recognition and protection of indigenous and tribal peoples. This research uses qualitative research method with case study approach. Research data obtained through interviews and document studies. The results of this study indicate that the policy of recognition and protection of indigenous and tribal peoples has not been formed because it is influenced by weak capacity of local government and strong corporate interests. Meanwhile, the participation of indigenous peoples and civil society is a factor that supports democratic governance in the recognition and protection of indigenous and tribal peoples.
\end{abstract}

Keywords: democratic governance, customary law community, recognition, protection

\section{Introduction}

Customary law research and studies have been undertaken by experts from various scientific backgrounds such as those conducted by Ubink \& Quan [1], Glaskin \& Weiner [2], Kishindo [3], Ngidang [4], Wright [5] and Wily [6]. However, most of these writings are dominated by legal perspective. Therefore, this paper tries to analyze from different side by using democratic governance perspective on implementation of customary law protection and recognition in Indragiri Hulu Regency of Riau Province.

The phenomenon occurring in Indragiri Hulu district indicates that the existence of customary law is still not fully recognized and protected because there is no Regional Regulation or Bupati Regulation that regulates the issue of customary law. The absence of a Regional Regulation and a Regent's Regulation resulted in a conflict between the company and the adat community, the government and the adat community, or among the indigenous peoples themselves. This paper aims to answer the research question that is why the Local Government Indragiri Hulu Regency has not been able to make policies that regulate the recognition and protection of indigenous peoples?

\section{Method}

This study uses qualitative research methods. The use of qualitative methods is intended to know the meaning of the phenomena that exist. Corbin \& Strauss in Taylor, S. J., Bogdan, R., 
\& DeVault [7] explain that the central to the phenomenological perspective and hence qualitative research is their own. The data collection used in this research is using technique proposed by Creswell [8], with qualitative observation, qualitative interviews, qualitative documents, and qualitative audio and qualitative materials. The data were obtained from informants from Talang Mamak customary community, Indigenous Peoples Alliance of Nusantara (AMAN) of Indragiri Hulu Regency, and Local Government of Indragiri Hulu Regency. The data analysis in this research is used when the data is collected and the analysis result is explored using democratic governance perspective.

\section{Result and Discussion}

The indigenous people of Talang Mamak are in Indragiri Hulu Regency already existed before the Unitary State of the Republic of Indonesia was formed. The history of the indigenous people of Talang Mamak is derived from the descendants of Pagarruyung Kingdom, especially with Datuk Perpatih Nan Sebatang [9]. The existence of Indigenous peoples of Talang Mamak has been recognized nationally in the 1945 Constitution of Article 18 B Paragraph (2) stating that "The State recognizes and respects the customary law communities and their traditional rights throughout their lives and in accordance with the development of the society and the principles of the Unitary State Republic of Indonesia, which is governed by the law. "Although there has been a national law base which recognizes the existence of customary law communities, the policy of the Central Government alone is insufficient because it does not guarantee the exercise of the rights of indigenous peoples.

Establishment of Minister of Home Affairs Regulation no. 52/2014 on Guidelines for the Recognition and Protection of Indigenous and Tribal Peoples, a reference for the Regional Government in taking concrete actions to enable the adat community to be recognized in the form of a Regional Head Decree. However, the Decree of the Head of Indragiri Hulu Regency in the recognition and protection of Talang Mamak indigenous peoples has not yet been established.

The problem in Indragiri Hulu District shows that the rights of the indigenous people of Talang Mamak still remain unfulfilled, especially towards access to natural resources such as forests, land, rivers, and mining resources within indigenous peoples. One of the conflicts is between PT. Runggu Prima Jaya with indigenous people Talang Mamak. The indigenous peoples of Talang Mamak are claiming their ulayat lands that have become oil palm plantations.

Recognition and protection of indigenous and tribal peoples is done first by identifying some basic elements such as; (1) the history of indigenous peoples, (2) customary territories, (3) customary law, (4) customary property and / or objects, and (5) customary government institutions / systems. In connection with the identification of Talang Mamak indigenous peoples in Indragiri Hulu regency, there have been efforts made by the Indragiri Hulu Regency Government by establishing a committee to discuss the recognition and protection of Talang Mamak indigenous peoples. However, the performance of the committee formed by the Government of Indragiri Hulu Regency has not been maximized due to the lack of participation from the Batin. Bevir [10]conveyed democratic governance affirming the existence of participation, pluralism, inclusion, empowerment, social justice, liberty, and equality. Thus, in the context of Indragiri Hulu District Government in the recognition and protection of Talang Mamak indigenous peoples is still less active participation of stakeholders, especially from the Batin. This participation is needed to accommodate input from interested parties so that the policy to be decided can be accepted by all parties. 
Some Kebatinan Talang Mamak have issued Information with a view to strengthening internal obedience to continue to fight to be recognized and protected by its communal rights. The information includes: (1) Strengthening togetherness through customary deliberations as the highest decision mechanism and binding for all Indigenous peoples of Talang Mamak, (2) Determined to map the Talang Mamak customary land in Batang Tanahku and (3) Dubalang Anak Talang, and Nan Anam Balai Nan Tiga (Tigabalai) which are our ancestral heritage, (4) Undertaking and customizing our adat history properly and correctly as the basis and the basis of customary and customary law, (5) Stop the actions of selling customary land, (6). Reinvesting adat and customary law and traditions as the identity and social identity of Talang Mamak's indigenous peoples, and (7) Maintaining the integrity of the Talang Mamak customary territories from any form of takeover and control by any external party.

Meanwhile, the factors that support the efforts to recognize and protect indigenous peoples Talang Mamak is the involvement of civil society. The role of civil society in the recognition and protection of Talang Mamak indigenous peoples is very dominant. NGOs such as the Indigenous Peoples Alliance of Nusantara (AMAN) of Indragiri Hulu Regency, Legal Aid Institute (LBH) Pekanbaru, and Malay Customary Institution (LAM) Riau play a very important role in advocating the policy of the Indragiri Hulu Regional Government. In fact, AMAN directly identifies and maps participatively Talang Mamak customary territory. Talang Mamak indigenous peoples consisting of 29 Kebatinan have mapped the region of some 15 kebatinan. Thus, with the participative mapping of Talah Mamak custom territory, the Regional Government may immediately make a Decree of the Regional Head even the Regional Regulation in recognizing and protecting the Talang Mamak customary community.

\section{Conclusion}

Efforts to recognize and protect Indigenous Peoples Talang Mamak in Indragiri Hulu Regency have been implemented but not yet optimal. Commitment from all parties especially the commitment of the Regional Government is needed in shaping the policy of recognition and protection of Talang Mamak indigenous peoples. The active participation of various stakeholders will build trust and produce the right policies. Civil society in the case of acknowledgment and protection of indigenous peoples Talang Mamak in Indragiri Hulu regency is very important. This indicates that the democratic governance characteristic in Indragiri Hulu Regency has been built and will continue to grow.

\section{Acknowledgment}

Special thanks to the author of the Institute of Education Fund (LPDP) for the scholarship received under the scheme of Indonesian National Lecturer (BUDI-DN).

\section{References}

[1] J. M. Ubink and J. F. Quan, "How to combine tradition and modernity? Regulating customary land management in Ghana," Land use policy, vol. 25, no. 2, pp. 198-213, 2008.

[2] K. Glaskin and J. Weiner, "Customary Land Tenure and Registration in Australia: Anthropological Perspectives.” p. 306, 2013.

[3] P. Kishindo, "Customary land tenure and the new land policy in Malawi," J. Contemp. African Stud., vol. 22, no. 2, pp. 213-225, 2004. 
[4] Ngidang, "Deconstruction and reconstruction of native customary land tenure in Sarawak," Japanese J. Southeast Asian Stud., vol. 43, no. 1, pp. 47-75, 2005.

[5] G. Wright, "Indigenous people and customary land ownership under domestic REDD+ frameworks: A case study of Indonesia," Law Env't Dev. J, vol. 7, p. 117, 2011.

[6] L. A. Wily, "Customary land tenure in the modern world, Rights to Resources in Crisis," Rev. Fate Cust. Tenure Africa, vol. 1, no. 5, 2011.

[7] R. S. J. Taylor, Bog, and M. DeVault, Introduction to qualitative research methods: A guidebook and resource. John Wiley \& Sons, 2015.

[8] J. W. Creswell, Research Design: Qualitative, Quantitative, and Mixed Methods Approaches. Los Angeles: Sage Publications, Inc, 2014.

[9] A. Isa and R. Astafi, "The Existing of Naqshbandi Tariqa and Its Influence on SocioCultural Life of the Sakai People in Bengkalis Regency," Wawasan J. Ilm. Agama dan Sos. Budaya, vol. 4, no. 1, pp. 80-93, 2019.

[10] M. Bevir, "Democratic governance.” Princeton University Press, 2010. 